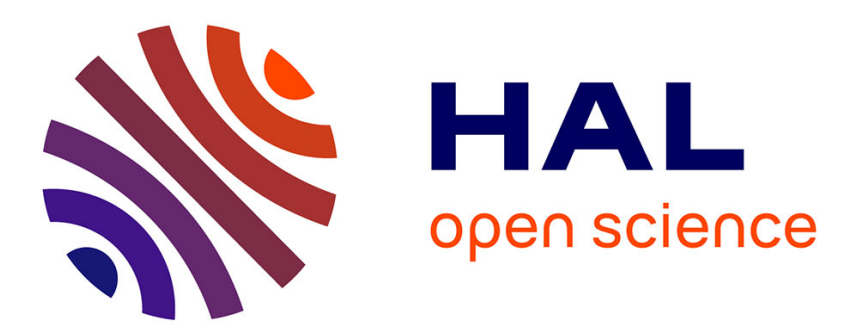

\title{
Mapping of plumage colour and blood protein loci on the microsatellite linkage map of the Japanese quail
}

M. Miwa, M. Inoue-Murayama, B.B. Kayang, Francis F. Minvielle, Jean Louis Monvoisin, H. Takahashi, S. Ito

\section{- To cite this version:}

M. Miwa, M. Inoue-Murayama, B.B. Kayang, Francis F. Minvielle, Jean Louis Monvoisin, et al.. Mapping of plumage colour and blood protein loci on the microsatellite linkage map of the Japanese quail. Animal Genetics, 2005, 36, pp.396-400. hal-02671018

\section{HAL Id: hal-02671018 https://hal.inrae.fr/hal-02671018}

Submitted on 31 May 2020

HAL is a multi-disciplinary open access archive for the deposit and dissemination of scientific research documents, whether they are published or not. The documents may come from teaching and research institutions in France or abroad, or from public or private research centers.
L'archive ouverte pluridisciplinaire HAL, est destinée au dépôt et à la diffusion de documents scientifiques de niveau recherche, publiés ou non, émanant des établissements d'enseignement et de recherche français ou étrangers, des laboratoires publics ou privés. 


\title{
Mapping of plumage colour and blood protein loci on the microsatellite linkage map of the Japanese quail
}

\author{
M. Miwa*, M. Inoue-Murayama*, B. B. Kayang ${ }^{\dagger, \uparrow}$, F. Minvielle ${ }^{\ddagger}$, J. L. Monvoisin ${ }^{\ddagger}$, H. Takahashi ${ }^{\S}$ \\ and S. Ito* \\ *Faculty of Applied Biological Sciences, Gifu University, Gifu 501-1193, Japan. 'Laboratoire de Génétique Cellulaire, Centre INRA de \\ Toulouse, BP 27 Auzeville, 31326 Castanet Tolosan, France. ${ }^{\ddagger}$ UMR Génétique et Diversité Animales, INRA bât 211, 78352 Jouy-en-Josas \\ Cedex, France. ${ }^{5}$ National Institute of Agrobiological Sciences, Tsukuba 305-8602, Japan. "Present address: Department of Animal Science, \\ College of Agriculture and Consumer Sciences, University of Ghana, Legon, Ghana
}

\section{Summary}

\begin{abstract}
The objective of this work was to map classical markers (plumage colours and blood proteins) on the microsatellite linkage map of the Japanese quail (Coturnix japonica). The segregation data on two plumage colours and three blood proteins were obtained from 25 three-generation families (193 $\mathrm{F}_{2}$ birds). Linkage analysis was carried out for these five classical markers and 80 microsatellite markers. A total of 15 linkage groups that included the five classical loci and 69 of the 80 microsatellite markers were constructed. Using the BLAST homology search against the chicken genome sequence, three quail linkage groups, QL8, QL10 and QL13, were suggested to be homologous to chicken chromosomes GGA9, GGA20 and GGA24, respectively. Two plumage colour loci, black at hatch (Bh) and yellow $(Y)$, and the three blood protein loci, transferrin (Tf), haemoglobin ( $\mathrm{Hb}-1)$ and prealbumin-1 (Pa-1), were assigned to CJA01, QL10, QL8, CJA14 and QL13, respectively.
\end{abstract}

Keywords blood protein, Japanese quail, linkage map, microsatellite, plumage colour.

\section{Introduction}

The Japanese quail (Coturnix japonica) was originally domesticated in Japan around the 11th century as a pet song bird (Crawford 1990). Nowadays, this poultry is commercially raised for egg production in Japan and East Asian countries, and for meat production in Western European countries such as Spain and France (Minvielle 2004). The domestic Japanese quail is also used as a laboratory animal for research in biomedical sciences and as a pilot animal for poultry production because of its small body size, short generation interval and high egg production (Padgett \& Ivey 1959; Wilson et al. 1961). Twenty-seven plumage colours and over 70 biochemical markers have been reported so far (Cheng \& Kimura 1990). While these are easily identifiable classical markers, only three linkage

Address for correspondence

Miho Inoue-Murayama, Faculty of Applied Biological Sciences, Gifu University, Gifu 501-1193, Japan.

E-mail: miho-i@cc.gifu-u.ac.jp

Accepted for publication 10 May 2005 groups based on them are known (Ito et al. 1988a,b; Shibata \& Abe 1996; Minvielle et al. 2000).

Recently, 100 microsatellite markers were developed for Japanese quail (Kayang et al. 2000, 2002) and used to build the first microsatellite linkage map, which spans $576 \mathrm{cM}$ and contains 58 loci assigned to 12 linkage groups (Kayang et al. 2004). As was the recently published AFLP map for Japanese quail (Roussot et al. 2003), this map is composed solely of type II markers. Morphological traits or type I markers have not been mapped in the Japanese quail yet.

The chicken (Gallus gallus) linkage map includes loci for plumage and skin colour, such as dermal melanin inhibitor (Levin et al. 1993), dominant white (Ruyter-Spira et al. 1997) and extension (Kerje et al. 2003), which were mapped on linkage groups GGAZ, E22C19W28 and GGA11, respectively. However, a relatively small number of classical markers have been mapped.

The objective of the present work was to map two quail plumage colour loci, yellow (Y) (Homma et al. 1967) and black at hatch (Bh) (Minezawa \& Wakasugi 1977), and three blood protein loci, specifically haemoglobin ( $\mathrm{Hb}-1)$, transferrin (Tf) and prealbumin-1 (Pa-1) (Cheng \& Kimura 1990). These plumage colour traits are controlled 
by autosomal dominant alleles with homozygous lethality. The heterozygote $Y /+$ shows a golden wheat-straw colour while the heterozygote $B h /+$ shows an overall black colour that obscures the pattern of black and yellow stripes. Neither of these two loci has been reported in other Phasianidae species.

\section{Materials and methods}

Japanese quail population

The $\mathrm{F}_{0}$ generation of the Gifu University resource population was composed of 24 males and 24 females single-pair mated to produce the $\mathrm{F}_{1}$ generation. A total of $193 \mathrm{~F}_{2}$ quail were produced by 25 single-pair mating of $\mathrm{F}_{1}$ birds. Thus a total of 291 birds (48 P, $50 \mathrm{~F}_{1}$ and $193 \mathrm{~F}_{2}$ ) were used for the linkage analysis. These families included two plumage colour families: seven for $Y\left(14 \mathrm{P}, 14 \mathrm{~F}_{1}\right.$ and $\left.61 \mathrm{~F}_{2}\right)$ and eight for $B h\left(16 \mathrm{P}, 16 \mathrm{~F}_{1}\right.$ and $51 \mathrm{~F}_{2}$ ). Because homozygosity for $B h$ and $Y$ is lethal, we designed the following cross: $(B h$ or $\mathrm{Y} /+) \mathrm{X}(+/+)$ as $\mathrm{P}$ and $(\mathrm{Bh}$ or $\mathrm{Y} /+) \mathrm{X}(+/+)$ as $\mathrm{F}_{1}$. These two plumage colour families did not overlap. In addition to the former 15 families, 10 families were used for linkage analysis of microsatellite markers and blood protein markers.

\section{Genotyping}

A total of 100 Japanese quail (Kayang et al. 2000, 2002) and three chicken-derived microsatellite markers (ADLO037, ADLO142 and ADLO255; Inoue-Murayama et al. 2001) were genotyped in the above Japanese quail population. Among them, 80 microsatellite markers that showed polymorphism in the resource population were used for the linkage analysis.

DNA was extracted from the peripheral blood using the QIAamp DNA Blood Kit (Qiagen, Valencia, CA, USA). PCR amplifications were carried out on a PCR Thermal Cycler (TaKaRa Biomedicals, Shiga, Japan) in $10 \mu \mathrm{l}$ reaction mixtures containing $14 \mathrm{ng}$ DNA template, $0.3 \mu \mathrm{m}$ forward and reverse primers, $130 \mu \mathrm{m}$ each $\mathrm{dNTP}, 10 \mathrm{~mm}$ Tris-HCl $(\mathrm{pH}$ 8.3), $50 \mathrm{~mm} \mathrm{KCl,} 1.5 \mathrm{~mm} \mathrm{MgCl}_{2}$ and $0.4 \mathrm{U}$ AmpliTaq Gold (Perkin-Elmer, Foster City, CA, USA). After an initial incubation at $95{ }^{\circ} \mathrm{C}$ for $9 \mathrm{~min}$, amplification reactions were performed for 30-42 cycles each with denaturing at $95{ }^{\circ} \mathrm{C}$ for $30 \mathrm{~s}$, annealing for $1 \mathrm{~min}$ at $48-69{ }^{\circ} \mathrm{C}$ depending on the optimized annealing temperature of the primer used, and extension at $72{ }^{\circ} \mathrm{C}$ for $1 \mathrm{~min}$. This was followed by a final cycle at $72{ }^{\circ} \mathrm{C}$ for $5 \mathrm{~min}$. PCR products of three to five markers were combined and electrophoresed simultaneously on an ABI Prism 3100 DNA Sequencer (PerkinElmer), and analysed using Genescan version 3.7 and the Genotyper version 3.7 softwares (Perkin-Elmer).

Quail from the Gifu University resource population were genotyped for three blood protein loci, specifically haemoglobin (Hb-1) (Maeda et al. 1975), transferrin (Tf) (Ito et al. 1981) and prealbumin-1 (Pa-1) (Tanabe \& Ogawa 1982).

\section{Data analysis}

To perform the comparative mapping with chicken, we checked the orthologous positions of quail microsatellite flanking sequences that were linked with classical markers using BLAST homology search against the chicken draft genome sequence (http://www.ncbi.nlm.nih.gov/genome// guide/chicken/).

Linkage analysis was performed using CriMap version 2.4 software (Green et al. 1990). Our genotyping data were merged with available microsatellite genotyping data from the INRA resource population $(n=497)$ (Kayang et al. 2004) to construct more informative microsatellite linkage map of the Japanese quail. A two-point linkage analysis of all markers was then made, based on a LOD score threshold of 3.0. Subsequently, the markers belonging to the same linkage group were analysed using the BUILD option and the order of different loci was examined with the FLIPS option. Map distances were derived using the Kosambi mapping function.

\section{Results}

Polymorphism was found in 80 of the 103 microsatellite markers tested in the two resource populations. Among them, 75 were polymorphic in the Gifu University resource population. The other five markers were polymorphic only in the INRA resource population. Linkage analysis was thus performed using a total of 85 loci composed of 80 microsatellites, two plumage colours $(B h$ and $Y$ ) and three blood proteins ( $\mathrm{Tf}, \mathrm{Hb}-1$ and $\mathrm{Pa}-1$ ). A total of 14 autosomal linkage groups and a $\mathrm{Z}$ chromosome-specific linkage group were obtained with the five classical markers and 69 microsatellite markers. These linkage groups covered a total map distance of $921 \mathrm{cM}$ with an average spacing of $11.8 \mathrm{cM}$ between loci. Informative meiosis of classical markers, $\mathrm{Bh}$, Y, Tf, Hb-1 and Pa-1, were 51, 61, 28, 58 and 237, respectively. The average informative meiosis of each microsatellite marker was 650 (7-1037).

Using BLAST homology search, orthologous sequences for quail microsatellite flanking sequences (GUJ0071, GUJ0065 and GUJ0061) were detected on the chicken chromosomes GGA9, GGA20 and GGA24, respectively (Table 1). Thus, three linkage groups, QL8 (with GUJ0071), QL10 (with GUJ0065) and QL13 (with GUJ0061) (Kayang et al. 2004), were homologous to chicken chromosomes GGA9, GGA20 and GGA24, respectively based on the high level of karyotype conservation between chicken and Japanese quail (Schmid et al. 2000; Shibusawa et al. 2001; Kayang et al. 2004).

The plumage colour loci $B h$ and $Y$ were mapped on CJA01 and the QL10 linkage group (homologous to GGA20), respectively (Fig. 1). The Bh locus was linked to GUJO077, GUJOO56 and ADLO037 (LOD = 4.30, 7.99 and 3.34 , respectively) and the marker order was GUJ0077GUJ0056-Bh-ADL0037. The $Y$ locus was linked to GUJ0083 $(\mathrm{LOD}=9.26)$, but it was not significantly linked 
Table 1 BLAST search of Japanese quail microsatellite flanking sequences with the chicken draft genome sequence.

\begin{tabular}{|c|c|c|c|c|c|c|}
\hline \multirow[b]{2}{*}{ Locus } & \multirow{2}{*}{$\begin{array}{l}\text { GenBank accession } \\
\text { number }\end{array}$} & \multirow{2}{*}{$\begin{array}{l}\text { Japanese quail } \\
\text { linkage group }\end{array}$} & \multirow{2}{*}{$\begin{array}{l}\text { Chicken chromosome } \\
\text { number }\end{array}$} & \multirow{2}{*}{$\begin{array}{l}\text { Map position on the } \\
\text { chicken chromosome (bp) }\end{array}$} & \multicolumn{2}{|c|}{$\begin{array}{l}\text { Nucleotide similarity } \\
\text { between Japanese quail } \\
\text { and chicken }(\%)^{1}\end{array}$} \\
\hline & & & & & $5^{\prime}$ flank $^{2}$ & $3^{\prime}$ flank $^{2}$ \\
\hline GUJ0061 & AB063129 & QL13 & GGA24 & $4938043-4938201$ & 96.2 (104nt) & 95.0 (37nt) \\
\hline GUJ0065 & AB063133 & QL10 & GGA20 & 7845 119-7 845404 & $96.8(61 \mathrm{nt})$ & 90.0 (20nt) \\
\hline GUJ0071 & AB063139 & QL8 & GGA9 & 2999 650-2 999794 & 100 (12nt) & $89.5(111 \mathrm{nt})$ \\
\hline
\end{tabular}

${ }^{1}$ Nucleotide similarities of original Japanese quail markers were calculated by the BLAST homology search against the chicken draft genome sequence (http://www.ncbi.nlm.nih.gov/genome//guide/chicken/).

${ }^{2} 5^{\prime}$ and $3^{\prime}$ flanking sequences of the microsatellite.

with GUJ0065 because GUJ0065 was polymorphic only in two families (number of available $\mathrm{F}_{2}=16, \theta=0.25$, LOD $=0.91$ ). Because GUJO065-GUJ0083 linkage was also supported by a high LOD score $(=35.3)$ and double recombination rarely occurs in a short chromosome region,
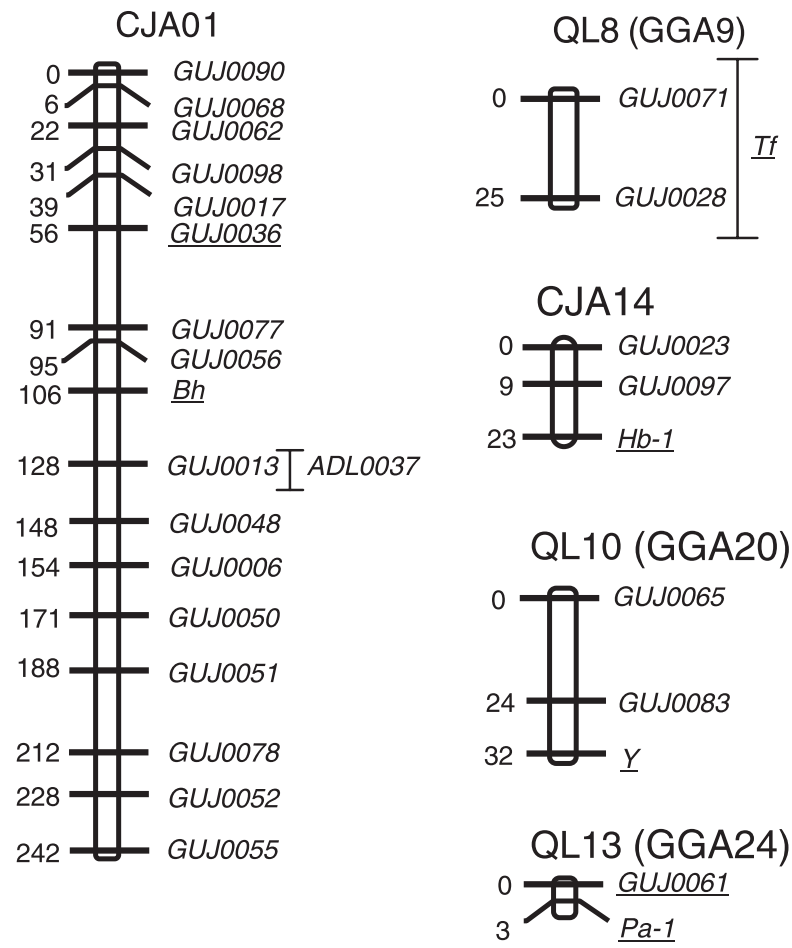

Figure 1 Sex-averaged genetic linkage map of CJA01, QL8, CJA14, QL10 and QL13 in Japanese quail (Coturnix japonica). The QL8, QL10 and QL13 linkage groups possibly correspond to chicken chromosome in the parenthesis based on BLAST homology search. The genetic linkage map based on a LOD score threshold of 3 is shown with the estimated Kosambi map distances in centimorgan ( $\mathrm{cM}$ ) on the left. The order of loci on the framework map is supported by odds $>3$ and the possible locations of the remaining loci are indicated by the error bar. Microsatellite markers named GUJ are original Japanese quail markers (Kayang et al. 2000, 2002) while ADL0037 (Cheng et al. 1995) is a chicken-derived marker. Five classical markers ( $B h, T f, H b-1, Y$ and $\mathrm{Pa}-1$ ) and two microsatellite markers (GUJ0036 and GUJ0061) newly mapped in this study are underlined. marker order was calculated GUJ0065-GUJ0083-Y using CriMap version 2.4 software.

The blood protein loci $\mathrm{Tf}, \mathrm{Hb}-1$ and $\mathrm{Pa}-1$ were linked to GUJ0071, GUJ0097 and GUJO061 (LOD = 3.80, 5.44 and 28.9), respectively, and were mapped on QL8 (homologous to GGA9), CJA14 and QL13 (homologous to GGA24), respectively (Fig. 1).

\section{Discussion}

Three linkage groups were suggested to be homologous to chicken chromosomes by the BLAST homology search. Cytogenetic studies based on banding patterns or chromosome painting using fluorescent in situ hybridization (FISH) revealed highly conserved chromosome homology and orthologous chromosome number between Japanese quail and chicken (Schmid et al. 2000; Shibusawa et al. 2001). In the previous study, six linkage groups including CJA01 and CJA14 have provisionally been assigned to quail chromosomes through comparative mapping with chicken using the cross-species markers (Kayang et al. 2004). Because results in this study were not enough to assign linkage groups to quail chromosomes, we have used linkage group numbers from the previous study (Kayang et al. 2004).

The location of $B h$ around the middle of the CJA01 linkage group supports the observation from FISH studies that this locus was mapped on the long arm of chromosome 1 using the flanking sequence of $B h$ as a probe (Niwa et al. 2003). The analysis of the expression pattern of genes relating to melanocyte development and melanins pigment production in $B h$ and wild-type quail embryos throughout development revealed an abnormal expression pattern of the MelEM antigen in homozygous and heterozygous embryos (Niwa et al. 2002). Identification of the Bh gene will be possible in the near future by combining information of chromosome location, chicken genome sequence (International Chicken Genome Sequencing Consortium 2004), and gene expression pattern. In contrast, there is no direct evidence for the function of $Y$, which was mapped on the QL10 linkage group (homologous to GGA20) in Japanese quail. This mutation might be agouti-like; it has the same 
dominant lethal genetic determinism and it induces a uniform yellow colour as does the agouti mutation $A^{y}$ in the mouse (Michaud et al. 1993). The chicken expressed sequence tag (EST) homologous to agouti signalling protein (ASIP) has already been sequenced (BBSRC ChickEST Database: http://chick.umist.ac.uk/) and was mapped on GGA20 by BLAST search. Because of these points, ASIP is suggested to be the candidate gene for the $Y$ locus.

Blood protein loci have been located in many species such as humans, mouse and chicken (NCBI Genomic Biology web page: http://www.ncbi.nih.gov/Genomes/). Transferrin, haemoglobin and prealbumin-1 are mapped onto the genetic linkage map of the Japanese quail for the first time in this study. In the present study, genetic information in the chicken suggests that the $H b-1$ polymorphism mapped on CJA14 is based on the polymorphism of the haemoglobin $\alpha$ chain locus (HBA), because the HBA locus in chicken is located on homologous GGA14 (ARKdb: http://www. thearkdb.org/). The $T f$ locus was mapped on the QL8 linkage group (homologous to GGA9) in Japanese quail, and the ovotransferrin locus (Jeltsch \& Chambon 1982) is also located on homologous GGA9, which suggests that both ovotransferrin and serum transferrin polymorphisms may be controlled by the same locus in the Japanese quail (Kimura et al. 1978).

\section{Acknowledgements}

We gratefully acknowledge Dr M. Mizutani, Nippon Institute for Biological Science, and Mr Y. Inoue, Gifu University, for their technical supports. This study was partly funded by the 2001, 2002 and 2003 grants from Gifu University.

\section{References}

Cheng K.M. \& Kimura M. (1990) Mutations and major variants in Japanese quail. In: Poultry Breeding and Genetics (Ed. by R.D. Crawford), pp. 333-62. Elsevier, Amsterdam.

Cheng H.H., Levin I., Vallejo R.L., Khatib H., Dodgson J.B., Crittenden L.B. \& Hillel J. (1995) Development of a genetic map of the chicken with markers of high utility. Poultry Science 74, 1855-74.

Crawford R.D. (1990) Origin and history of poultry species. In: Poultry Breeding and Genetics (Ed. by R.D. Crawford), pp. 1-41. Elsevier, Amsterdam.

Green P., Falls K. \& Crooks S. (1990) Documentation for CRI-MAP. Washington University School of Medicine, St Louis.

Homma K., Shumiya S. \& Jinno M. (1967) Yellow-feathered Japanese quail (Coturnix coturnix japonica). Japanese Journal of Zootechnical Science 38, 163-6.

Inoue-Murayama M., Kayang B.B., Kimura K. et al. (2001) Chicken microsatellite primers are not efficient markers for Japanese quail. Animal Genetics 32, 7-11.

International Chicken Genome Sequencing Consortium (2004) Sequence and comparative analysis of the chicken genome provide unique perspectives on vertebrate evolution. Nature 432, 695-716.
Ito S., Asano H., Hanai H., Ishikawa K., Kimura M. \& Isogai I. (1981) Genetic control and population survey of transferrin in the Japanese quail. Animal Blood Groups and Biochemical Genetics $12,145-7$.

Ito S., Kimura M. \& Isogai I. (1988a) A sex difference in recombination values between extended brown and phosphoglucose isomerase loci in Japanese quail. Japanese Journal of Zootechnical Science 59, 801-5.

Ito S., Kimura M. \& Isogai I. (1988b) Linkage between panda plumage and albumin loci in Japanese quail. Japanese Journal of Zootechnical Science 59, 822-4.

Jeltsch J.M. \& Chambon P. (1982) The complete nucleotide sequence of the chicken ovotransferrin mRNA. European Journal of Biochemistry 122, 291-5.

Kayang B.B., Inoue-Murayama M., Nomura A., Kimura K., Takahashi H., Mizutani M. \& Ito S. (2000) Fifty microsatellite markers for Japanese quail. The Journal of Heredity 91, 502-5.

Kayang B.B., Inoue-Murayama M., Hoshi T., Matsuo K., Takahashi H., Minezawa M., Mizutani M. \& Ito S. (2002) Microsatellite loci in Japanese quail and cross-species amplification in chicken and guinea fowl. Genetics Selection Evolution 34, 233-53.

Kayang B.B., Vignal A., Inoue-Murayama M., Miwa M., Monvoisin J.L., Ito S. \& Minvielle F. (2004) A first-generation microsatellite linkage map of the Japanese quail. Animal Genetics 35, 195-200.

Kerje S., Lind J., Schütz K., Jensen P. \& Andersson L. (2003) Melanocortin 1-receptor (MC1R) mutations are associated with plumage colour in chicken. Animal Genetics 34, 241-8.

Kimura M., Ito S., Nagamine Y. \& Isogai I. (1978) Transferrin electrophoretic pattern of the quail Coturnix coturnix japonica. Japanese Poultry Science 15, 267-8.

Levin I., Crittenden L.B. \& Dodgson J.B. (1993) Genetic map of the chicken $\mathrm{Z}$ chromosome using random amplified polymorphic DNA (RAPD) markers. Genomics 16, 224-30.

Maeda Y., Hashiguchi T. \& Taketomi M. (1975) Genetic variation of hemoglobin in Japanese quail. The Japanese Journal of Genetics 50, $265-8$.

Michaud E.J., Bultman S.J., Stubbs L.J. \& Woychik R.P. (1993) The embryonic lethality of homozygous lethal yellow mice $\left(A^{y} / A^{y}\right)$ is associated with the disruption of a novel RNA-binding protein. Genes \& Development 7, 1203-13.

Minezawa M. \& Wakasugi N. (1977) Studies on a plumage mutant (black at hatch) in the Japanese quail. The Japanese Journal of Genetics 52, 183-95.

Minvielle F. (2004) The future of Japanese quail for research and production. World's Poultry Science Journal 60, 500-7.

Minvielle F., Ito S., Inoue-Murayama M., Mizutani M. \& Wakasugi N. (2000) Genetic analyses of plumage color mutations on the $\mathrm{Z}$ chromosome of Japanese quail. The Journal of Heredity 91, 499-501.

Niwa T., Mochii M., Nakamura A. \& Shiojiri N. (2002) Plumage pigmentation and expression of its regulatory genes during quail development - histochemical analysis using Bh (black at hatch) mutants. Mechanisms of Development 118, 139-46.

Niwa T., Shibusawa M., Matsuda Y., Terashima A., Nakamura A. \& Shiojiri N. (2003) The Bh (black at hatch) gene that causes abnormal feather pigmentation maps to chromosome 1 of the Japanese quail. Pigment Cell Research 16, 656-61. 
Padgett C.A. \& Ivey W.D. (1959) Coturnix quail as a laboratory research animal. Science 129, 267-8.

Roussot O., Feve K., Plisson-Petit F., Pitel F., Faure J.M., Beaumont C. \& Vignal A. (2003) AFLP linkage map of the Japanese quail Coturnix japonica. Genetics Selection Evolution 35, 559-72.

Ruyter-Spira C.P., Gu Z.L., Van der Poel J.J. \& Groenen M.A.M. (1997) Bulked segregant analysis using microsatellites: mapping of the dominant white locus in the chicken. Poultry Science 76, 386-91.

Schmid M., Nanda I., Guttenbach M. et al. (2000) First report on chicken genes and chromosomes 2000. Cytogenetics and Cell Genetics 90, 169-218.

Shibata T. \& Abe T. (1996) Linkage between the loci for serum albumin and vitamin D binding protein (GC) in the Japanese quail. Animal Genetics 27, 195-7.
Shibusawa M., Minai S., Nishida-Umehara C., Suzuki T., Mano T., Yamada K., Namikawa T. \& Matsuda Y. (2001) A comparative cytogenetic study of chromosome homology between chicken and Japanese quail. Cytogenetics and Cell Genetics 95, 103-9.

Tanabe H. \& Ogawa N. (1982) Mode of inheritance of a newly found protein polymorphism in prealbumin $(\mathrm{Pa}-1)$ zone in the plasma of the Japanese quail (Coturnix coturnix japonica). Japanese Poultry Science 19, 269-71.

Wilson W.O., Abbott U.K. \& Abplanalp H. (1961) Evaluation of Coturnix (Japanese quail) as pilot animal for poultry. Poultry Science 40, 651-7. 